Hydrol. Earth Syst. Sci. Discuss., https://doi.org/10.5194/hess-2018-222

Manuscript under review for journal Hydrol. Earth Syst. Sci.

Discussion started: 23 May 2018

Hydrology and

\title{
A novel model for simulation of nitrate in aquifers
}

\author{
Roohollah Noori ${ }^{1}$, Mehrnaz Dodangeh${ }^{1}$, Ronny Berndtsson ${ }^{2}$, Farhad Hooshyaripor ${ }^{3}$, Jan Franklin
} Adamowski $^{4}$, Saman Javadi ${ }^{5}$, Akbar Baghvand ${ }^{1}$

${ }^{1}$ Department of Environmental Engineering, Graduate Faculty of Environment, University of Tehran, Tehran, 1417853111, Iran

${ }^{2}$ Department of Water Resources Engineering \& Center for Middle Eastern Studies, Lund University, Box 118, SE-221 00 Lund, Sweden

${ }^{3}$ Department of Civil Engineering, Science and Research Branch, Islamic Azad University, Tehran, 1477893855, Iran

${ }^{4}$ Department of Bioresource Engineering, Faculty of Agricultural and Environmental Sciences, McGill University, Montreal,

10 H9X 3V9, Canada

${ }^{5}$ Department of Irrigation and Drainage, Aburaihan Campus, University of Tehran, Tehran, 3391653755, Iran

Correspondence to: Roohollah Noori (noor@ut.ac.ir)

Abstract. Please Numerical groundwater quality models (GQMs) often run at high computational cost resulting in long simulation times and complex parameter calibration that limit their practical applications. In this study, a novel reduced-order model (ROM) was developed for nitrate simulation in groundwater including a simple structure and with similar accuracy as more extensive GQMs. The proposed methodology for the development of ROM presents a solution for the problem in ROMs developed with eigenvectors, to make predictions into the future. The model performance was investigated by simulation of nitrate in the Karaj Aquifer, Iran. The dominant modes of spatiotemporal variation of nitrate during a five-year period was calculated by the model. The results revealed an excellent agreement between nitrate simulated by the ROM and the wellknown Modular Transport 3D Multi Species (MT3DMS). The absolute error between the ROM and the MT3DMS was less than $0.5 \mathrm{mg} / 1$ in the most parts of the aquifer. Thus, results confirm that the use of ROM has advantages through a much simpler structure and shorter calculation times. Observed spatiotemporal variation of nitrate in the aquifer was well represented by the ROM simulations. The simplicity of the model makes it highly interesting also to other water resources problems.

\section{Introduction}

25 High dependency on groundwater resources and excessive water withdrawal from aquifers have led to drastic drop in groundwater levels in many parts of the world. In addition, agricultural, industrial, and urban activities may be resulted in pollution spread in the aquifers that finally result in groundwater quality deterioration. In this regard, nitrate is often a main concern for most aquifer water quality. Studying the spatiotemporal variation (STV) of nitrate in aquifers provides important information for effective management of the contaminated groundwater resources and possibilities for future improvement. Due to lack of proper groundwater monitoring systems as well as small research budgets especially in developing countries, groundwater quality simulation models (GQSMs) are essential for evaluation of the STV of nitrate in these aquifers. The 
Hydrol. Earth Syst. Sci. Discuss., https://doi.org/10.5194/hess-2018-222

Manuscript under review for journal Hydrol. Earth Syst. Sci.

Discussion started: 23 May 2018

(c) Author(s) 2018. CC BY 4.0 License.

models can provide important information regarding the present status and implications of future scenarios regarding the STV of nitrate contamination.

A literature review clearly demonstrates the successful applications of one of the most popular GQSMs, the Modular Transport 3D Multi Species (MT3DMS) (Zheng and Wang, 1999; Conan et al., 2003; Peña-Haro et al., 2009 and 2010; Saghravani et

5 al., 2011; Rasmussen et al., 2013; Gusyev et al., 2014; Abdelaziz and Merkel, 2015; Pulido-Velazquez et al., 2015; Laattoe et al., 2017). Three important challenges, however, as discussed below, influence such models regarding management decisions based on their results: (A) In many cases (especially the use of three-dimensional models with long simulation times for pollutants in extended aquifers), the computational costs are very high and the large amount of information produced by the models is confusing ( $\mathrm{Li}$ et al., 2004; Vermeulen et al., 2005; Stanko et al., 2016). This poses challenges regarding decision

10 making and proper management of the aquifers. In such cases, application of alternative methods such as reduced-order models (ROMs) based on proper orthogonal decomposition (POD) may be an alternative (Esfahanian and Ashrafi, 2009). The accuracy of ROMs has been shown to be compatible with GQSMs while ROMs pose a much simpler structure (Cardoso et al., 2009; Ushijima and Yeh, 2017). In ROMs based on eigenvectors the dominant spatiotemporal modes of the target are calculated. Using the few first dominant modes, a simple model is developed to simulate the target. Successful application of this approach

15 in the field of water resources management (beyond the laboratory scale in which many simplifying assumptions may be employed) has been reported for simulation of nitrate and water temperature in the Karkheh Dam Reservoir located in Iran (Noori et al., 2015 and 2018) and surface currents in the Gorgan Bay, Iran (Kheirabadi et al., 2018). Some other studies have aimed at applying ROMs in subsurface flow (Vermeulen et al., 2004, 2005 and 2006; McPhee and Yeh, 2008; Siade et al., 2010; Pasetto et al., 2011, 2013 and 2014; Stanko et al., 2016), however, no applications have been reported using them to

20 quantify pollutants in aquifers. Due to the difficulty of ROMs to make predictions into the future as described by Noori et al. (2017), the above work (Noori et al., 2015) only aimed at regeneration of nitrate in the reservoir during the simulation period. Therefore, the most important goal of this study was to develop a ROM based eigenvectors that can predict the future concentration of nitrate in the aquifer (beyond the observation period). (B) The second challenge in application of GQSMs is their limitation in providing the dominant modes of the pollutant variation in the simulation period. GQSMs can provide STV

25 of pollutants in the aquifer and deliver useful information for water quality managers. But, when the aim is determining the dominant modes of the pollutant, the user needs to use an alternative solution like POD linked to the GQSMs (Kostas et al., 2005; Bennacer and Sefiane, 2016). The POD can use snapshots of pollutant distribution simulated by GQSMs, thus, determining the dominant modes of pollutant variation. These dominant modes appropriately present the most representative patterns of STV of pollutant in the simulation period (Kang et al., 2015). To the best of the authors' knowledge, no application

30 has yet been reported aiming to present dominant modes of STV for pollutants in groundwater systems. (C) Finally, the third challenge for application of QGSMs is the complex mathematical form of the governing equations as well as their complicated solving methods (Mehl, 2006; Stanko et al., 2016; Pasetto et al., 2017). Fortunately, the ROMs overcome this problem to a large extent by providing a model with much simpler mathematical form than the QGSMs whilst they keep an acceptable level of accuracy (Boyce et al., 2015). 
Hydrol. Earth Syst. Sci. Discuss., https://doi.org/10.5194/hess-2018-222

Manuscript under review for journal Hydrol. Earth Syst. Sci.

Discussion started: 23 May 2018

In view of the above, in the present study, we modify the developed nitrate ROM with eigenvectors so that it enables prediction of nitrate STV in the Karaj Aquifer in the future time. The dominant modes of the nitrate variation in the aquifer are calculated and presented. In this regard, the groundwater flow in the study area was firstly simulated by MODFLOW (Harbaugh et al., 2000). Thereafter, STV of nitrate was calculated by MT3DMS model. Finally, the nitrate ROM was developed for the aquifer.

5 The presented methodology in this study is novel and it has broad applications in other fields of science and engineering.

\section{Methods}

\subsection{Study area}

The study area is the large unconfined groundwater Karaj aquifer with an area of $175.6 \mathrm{~km}^{2}$ located in the southern parts the Alborz Mountain chain (Figure 1). The mean annual rainfall from 1967 to 2012 was $285.5 \mathrm{~mm}$, with a coefficient of variation

10 of $30.3 \%$. The minimum and maximum annual values of rainfall were 93.3 and $452.6 \mathrm{~mm}$, respectively, whilst the average annual evaporation was about $2430 \mathrm{~mm}$. The only permanent river in the study area is the Karaj River with an average annual flow of 470 million cubic meters (MCM) that flows through the eastern region of the aquifer. The northern part is mountainous including high-altitude areas that are generally covered with fine-grain alluvial deposits, while the low-altitude areas in the southern part are coarse-grained alluvial deposits. In general, the study area has a relatively sharp slope with north and northeast

15 to south and southwest direction. It results in variation of land surface topography in the study area from $1381 \mathrm{~m}$ in the northeast to $1200 \mathrm{~m}$ in the south-west of the plain.

Due to its proximity to the Tehran metropolis, Karaj city has a high population density that has led to increasing water demand. To meet the water demand, groundwater withdrawal has increased resulting in a significant drop in water level and also groundwater quality degradation especially in the recent years. There are 12 observation wells (piezometers) in the study area

20 (Figure S1). The water level monitoring in these wells, clearly shows that the aquifer is experiencing a decreasing trend (typically 1.14 m per year water level decrease from April 2006 to April 2012).

\subsection{Groundwater flow and nitrate transport models}

To simulate the groundwater flow and nitrate transport in the Karaj Aquifer, MODFLOW and the Modular Transport 3D Multi Species (MT3DMS) models (Harbaugh et al., 2000; Zheng and Wang, 1999), respectively, were used. Figure 2 shows the 25 different steps of conducting the present study. MODFLOW is a three-dimensional (3D) model originally developed by the US Geological Survey that uses a block-centered finite difference technique to solve the groundwater flow equations in the saturated aquifers. The general governing equation solved by MODFLOW is:

$\frac{\partial}{x_{i}}\left(K_{i} \frac{\partial h}{x_{i}}\right)+q_{s}=S_{s} \frac{\partial h}{\partial t}$ 
Hydrol. Earth Syst. Sci. Discuss., https://doi.org/10.5194/hess-2018-222

where $K_{i}$ is hydraulic conductivity along $i$ axis $(\mathrm{m} / \mathrm{s}), x_{i}$ is the distance along the respective Cartesian coordinate axis $(\mathrm{m}), q_{s}$ is volumetric flux per unit volume ( $1 / \mathrm{s}), S_{s}$ is specific storage $(1 / \mathrm{m}), h$ is the potentiometric head $(\mathrm{m})$, and $t$ is time (s) (Abdelaziz and Zambrano-Bigiarini, 2014; Abdelaziz and Le, 2014).

The flow pattern simulated by MODFLOW was used as input to MT3DMS, developed by Zheng and Wang (1999), to simulate

5 the nitrate concentration in the aquifer. The partial differential equation describing the transport of contaminants in 3D transient groundwater flow systems can be written as:

$\frac{\partial(n C)}{\partial t}=\frac{\partial}{\partial x_{i}}\left(n D_{i j} \frac{\partial C}{\partial x_{i}}\right)-\frac{\partial}{\partial x_{i}}\left(n v_{i} C\right)+q_{s} C_{s}+\sum R_{n}$

where $C$ is dissolved concentration of nitrate $(\mathrm{g} / \mathrm{l}), n$ is porosity of the medium, $D_{i j}$ is hydrodynamic dispersion coefficient tensor $\left(\mathrm{m}^{2} / \mathrm{s}\right), v_{i}$ is the seepage or linear pore water velocity $(\mathrm{m} / \mathrm{s})$ calculated according to Eq. (3), $C_{s}$ is concentration of the source or sink flux $(\mathrm{g} / \mathrm{l})$ and $\sum R_{n}$ is chemical reaction term $(\mathrm{g} \backslash \mathrm{l}-\mathrm{s})$.

$v_{i}=-\frac{K_{i}}{n} \frac{\partial h}{\partial x_{i}}$

MODFLOW requires aquifer geometry, initial estimate of hydrodynamic parameters (hydraulic conductivity and storage coefficients), discharge of operational wells and their returned flow, amount of recharge, piezometers' information, and boundary and initial conditions as inputs. MT3DMS, in addition to the MODFLOW outputs, needs dispersion coefficients and

15 nitrate loads as initial and boundary condition.

According to geological studies, the Karaj Aquifer is a single-layer unconfined aquifer. The aquifer's thickness in different locations is illustrated in Figure S2. It varies from 86 to $347 \mathrm{~m}$ as presented in the figure. Evaluation of the water table in the piezometers reveals that the groundwater flows from north and northwest to the south and southwest of the aquifer. Thus, the boundary conditions are defined as two boundary lines including given heads at the north-western part of the aquifer for the entrance and at the southern part of the aquifer for the outflow (red lines in Figure S1). For instance, the iso-water table for April 2011 is shown in Figure S1. For the other boundaries there is no interaction between the adjacent aquifers.

The spatial distribution hydraulic conductivity was obtained by the Ministry of Energy that estimated these parameters from pumping tests. Initial values of specific yield were chosen on the basis of the guideline suggested by Johnson (2012). The final values of the hydraulic conductivity and specific yield are determined during the calibration stage.

25 There are 1,698 production wells used for different purposes such as industrial and agricultural activities (Figure S1). Using the information from these wells and land use (Figure S1), the groundwater discharge and water return coefficients for each land use type were calculated. The evaporation from groundwater was considered negligible since the groundwater table is deeper than three meter in all parts of the aquifer.

Besides natural rainfall infiltration, seepage from pit latrines is one of the sources of aquifer recharge due to vast use of this

30 system for wastewater disposal in the residential areas. The recharge amount from pit latrines was estimated based on population density and land use maps included in the calibration procedure. Karaj River is the other source of groundwater 
Hydrol. Earth Syst. Sci. Discuss., https://doi.org/10.5194/hess-2018-222

Manuscript under review for journal Hydrol. Earth Syst. Sci.

Discussion started: 23 May 2018

(c) Author(s) 2018. CC BY 4.0 License.

recharge in the study area. Note that at the entrance point of the river into the plain, part of water is diverted and transferred by a channel to supply drinking water of the surrounding towns. According to available data, mean annual depth of the river at the entry point to the plain for 2006-2008, 2008-2010, and 2010-2012 was 76.7, 92.8, and $66.7 \mathrm{~cm}$, respectively. At the outlet of the river from the plain, the river had typically insignificant flow for all years.

5 The spatial distribution of nitrate in April 2006 was used as initial conditions for the transport model. By using estimates of water recharge from different agricultural, industrial, and residential land uses and nitrate concentrations in recharged water, the nitrate loads into the aquifer were calculated. The nitrate loads were then calibrated according to those measured in the piezometers.

\subsection{Calibration and verification}

10 A six-year period from April 2006 to March 2012 was selected for calibration of the flow (MODFLOW) and nitrate transport (MT3DMS) models under unsteady state condition. This period was selected due to including the most accurate and complete data such as meteorological, hydrological, geological, hydrogeological, and water quality data. In addition, April 2011 was considered for calibration of the groundwater flow model under steady state condition. To verify the unsteady models' robustness, monthly data from April 2012 to March 2013 was employed.

\section{2.3.1 Groundwater flow model (MODFLOW)}

The aquifer was divided into a $100 \times 100$ gridded network with $217.9 \times 183 \mathrm{~m}$ mesh dimension. The number of active and inactive cells in the model were 4,691 and 5,309, respectively. In order to calibrate the model under steady state conditions, firstly, the piezometer data in April 2011 were used in the model as initial values. Note that spatially distributed groundwater levels for the aquifer were generated from piezometer data by kriging. In the next step, the model's calibration was performed

20 manually by adjustment of hydraulic conductivities. Input recharge was affected by great uncertainty, thus, they were simultaneously modified in the calibration process. The calibration process was continued until the Mandle (2002) criterion was met (difference between simulated and observed hydraulic heads less than $10 \%$ of the domain variation). The maximum domain variation was considered $10 \mathrm{~m}$. Spatial variation of calibrated hydraulic conductivity and recharge are shown in Figures S3 and S4, respectively. According to the figure, highest hydraulic conductivity is more than $45 \mathrm{~m} /$ day in the southwest part,

25 while minimum is about $4 \mathrm{~m} /$ day in the northwest. Spatial distribution of the calibrated recharge indicates that the urban densely populated areas experience high recharge values of more than $10 \mathrm{~mm} /$ day. The widespread using of pit latrines and wells for wastewater disposal may contribute the high rate of recharge in the urban areas.

In the next step the specific yields were calibrated under unsteady state condition. In this process, monthly time series of calibrated recharge, piezometer, and operational well data were used as model input. Considering $10 \mathrm{~m}$ accuracy of hydraulic

30 head in the model domain, the spatial variation of calibrated specific yields is shown in Figure S5. According to the figure, the specific yield varies from 0.15 in the south to 0.01 in the north of the aquifer.

After calibration, the model was verified for the period April 2012 to March 2013. 
Hydrol. Earth Syst. Sci. Discuss., https://doi.org/10.5194/hess-2018-222

Manuscript under review for journal Hydrol. Earth Syst. Sci.

Discussion started: 23 May 2018

\subsubsection{Contaminant transport model (MT3DMS)}

In MT3DMS model, there are five methods for solving the governing partial differential equations: method of characteristics, modified method of characteristics, hybrid method, finite difference, and ultimate methods. In the present study, the ultimate method, which is a combination of four other methods, was used to discretize the advection-diffusion equation. The model

5 was calibrated with trial and error. For this purpose, nitrate concentrations in April 2006 were used as initial conditions. Then, calibration of the model during the six-year period was done by modifying dispersion coefficients and nitrate input loads. Note that as the aquifer is single layer and unconfined, only longitudinal and transverse dispersion coefficients were calibrated in the model. Due to the fact that porosity is almost equal to the specific yield in unconfined course-graded aquifers, the calibrated specific yield was used for porosity in the calibration of the MT3DMS model. A threshold of $10 \%$ of nitrate variation during

10 the simulation period was attained (here $10 \mathrm{mg} / \mathrm{l}$ ).

After calibration of the MT3DMS, verification was carried out for a one-year period (April 2012 to March 2013).

\subsection{Nitrate ROM}

After calibration and verification of the flow and nitrate transport models for the Karaj Aquifer, the nitrate ROM was developed. A POD model was used in a first step to determine dominant modes of nitrate variation for the Karaj Aquifer. The

15 POD was applied to nitrate concentration simulations by MT3DMS for the aquifer $(\boldsymbol{\Omega})$ resulting in spatial components of dominant modes of nitrate concentrations $(\boldsymbol{\Theta})$ given by:

$\Theta=\sum_{i=1}^{N} \xi \Omega^{(\mathrm{i})}(\mathbf{x})$

In Eq. (4), $N$ is the number of snapshots, $\mathbf{x}$ is the location matrix of cells, and $\xi$ is the eigenvectors (Ashrafi, 2012). This relationship is a linear combination of snapshots taken from nitrate simulated in the Karaj Aquifer. To increase the similarity

20 between functions $\boldsymbol{\Theta}$ and $\boldsymbol{\Omega}$, it is necessary to determine $\xi$ in such a way that the following expression is optimized (Noori et al., 2015):

$\frac{1}{N} \sum_{i=1}^{N}\left\{\left|\left(\boldsymbol{\Omega}^{(i)}, \boldsymbol{\Theta}\right)\right|^{2} /(\boldsymbol{\Theta}, \boldsymbol{\Theta})\right\} \quad$ if $\quad(\boldsymbol{\Theta}, \boldsymbol{\Theta})=\|\boldsymbol{\Theta}\|^{2}=1$

The optimization of Eq. (5) is done by solving the following eigenvalue problem:

$\sum_{j=1}^{N} \mathbf{M}_{i j} \xi_{j}=\lambda \xi_{i}$

25 where $\mathbf{M}, \lambda$, and $\xi$ are Hermitian matric, eigenvalues, and their corresponding eigenvectors, respectively (Noori et al., 2015). Having the function $\Theta$ and using Eq. (7), the temporal components of dominant modes of nitrate in the Karaj Aquifer can be calculated (Ashrafi, 2012):

$\tau_{i}(t)=\left(\Omega(\mathbf{x}, t), \boldsymbol{\Theta}_{i}(\mathbf{x})\right)$ 
Hydrol. Earth Syst. Sci. Discuss., https://doi.org/10.5194/hess-2018-222

Manuscript under review for journal Hydrol. Earth Syst. Sci.

Discussion started: 23 May 2018

It is noteworthy that all eigenvalues calculated by Eq. (6) are positive. Only the few first calculated eigenvalues are large and the rest are close to zero. Since the calculated modes are corresponding to eigenvalues, only the few first modes are important in practical problems so that they represent most of the system variation (STV of nitrate concentration in the aquifer). Thus, it is possible to generate the STV of nitrate concentration in the aquifer by means of the first modes and application of the

5 following equation (Noori et al., 2017):

$\boldsymbol{\Omega}(\mathbf{x}, t) \cong \sum_{i}^{l} \tau_{i}(t) \boldsymbol{\Theta}_{i}(\mathbf{x}) \quad, \quad l \ll N$

where $l$ is the number of modes.

Eq. (8) has a simple structure with a few modes. Note that to be able to develop the nitrate concentration ROM by application of Eq. (8), one need simulated nitrate concentrations from the MT3DMS. In order to circumvent this problem, we develop a

10 methodology that enables the ROM to independently simulate nitrate concentrations. For this purpose, it is necessary to calculate both the spatiotemporal components $\boldsymbol{\Theta}(\mathbf{x})$ and $\tau(t)$ for the future time interval $(t+n)$. Since the component $\boldsymbol{\Theta}$ is a function of space, it does not change in time. Therefore, it is necessary to calculate $\tau$ for future time steps. For this purpose, a regression equation was used to estimate the time variation of this component $(\tau(t+n))$. Having $\tau(t+n)$, the nitrate concentration for future time steps $t+n$ can be calculated by:

$15 \Omega(\mathbf{x}, t+n) \cong \sum_{i=1}^{l} \tau_{i}(t+n) \boldsymbol{\Theta}_{i}(\mathbf{x}) \quad, \quad l \ll N$

Eq. (9) simulates the nitrate concentration in different parts of the aquifer for future time $t+n$ using the first few modes.

\section{Results and discussion}

\subsection{Results of groundwater flow model}

The calibration of MODFLOW was continued by six-year data from April 2006 to March 2012 until the difference between

simulated and observed groundwater levels for steady state condition in all piezometers was less than $10 \%$ of the hydraulic load variation within the domain (i.e., $10 \mathrm{~m}$ ). In addition, the difference between simulated and measured groundwater levels during the groundwater calibration for unsteady conditions are shown in Figures 3A and 3B for two piezometers. As seen from the figures, simulated piezometer levels match the observations well. Errors during calibration period were less than $10 \%$ of the hydraulic head variation (i.e., $\pm 10 \mathrm{~m}$ ) as suggested by Mandle (2002).

25 After successful calibration of the groundwater flow model, its performance was verified using data from April 2012 to March 2013 as shown in Figure 3C. According to the figure, the temporal variation of mean absolute error (MAE) and root mean square error (RMSE) is between 2.6 and $4.2 \mathrm{~m}$. Therefore, it can be concluded that the groundwater flow model was reliably calibrated and verified for the aquifer. 
Hydrol. Earth Syst. Sci. Discuss., https://doi.org/10.5194/hess-2018-222

Manuscript under review for journal Hydrol. Earth Syst. Sci.

Discussion started: 23 May 2018

Hydrology and

Earth System

(c) Author(s) 2018. CC BY 4.0 License.

Sciences

Discussions

(c) $\underset{\mathrm{BY}}{\mathrm{B}}$

\subsection{Results of nitrate transport model}

To properly tune the model, a threshold value of $10 \%$ of nitrate variation in the simulation period would be acceptable (here $10 \mathrm{mg} / \mathrm{l})$. Figures 3D to $3 \mathrm{~F}$ show the difference between simulated vs measured nitrate concentration during the calibration of MT3DMS under unsteady conditions in three selected piezometers for the Karaj Aquifer. According to these figures,

5 MT3DMS calibration has been performed well so that the error between simulated vs measured nitrates is less than $10 \mathrm{mg} / \mathrm{l}$. Verification of the MT3DMS model was carried out using one-year data from April 2012 to March 2013. In this step, mean values of MAE and RMSE were equal to 2.3 and $2.9 \mathrm{mg} / \mathrm{l}$ for nitrate concentration, respectively. The spatial distribution of nitrate concentration in the Karaj Aquifer for six selected months is illustrated in Figures 4A to 4F. The figures show that the northern part of the aquifer are more exposed to the risk of nitrate contamination. Nitrate concentration in some parts exceeds

10 the maximum permissible limit $50 \mathrm{mg} / \mathrm{l}$ suggested by World Health Organization. A look at the land use map (Figure S1) indicates that these parts include densely populated urban areas that typically use pit latrines for wastewater disposal.

\subsection{Dominant modes of nitrate STV}

To calculate the dominant modes of nitrate STV in the Karaj Aquifer, snapshots of nitrate concentrations simulated by MT3DMS were used from the calibration period. Due to the low variation of nitrate in groundwater compared to surface water, 15 one-day intervals were selected for capturing variation. Consequently, according to the six-year simulation period, 1,772 snapshots of nitrate concentration were obtained for 4,691 active cells of the Karaj Aquifer. In other words, a matrix $\boldsymbol{\Omega}$ was formed with the dimension $1,772 \times 4,691$ as described in "Methods" section. By applying the POD on the matrix $\Omega$, firstly the Hermitian matrix was formed with dimension equal the number of snapshots, i.e., $1,772 \times 1772$. Thereafter, the eigenvalues and their corresponding eigenvectors were calculated. The results for the first ten eigenvalues are shown in Figure 5A. The

20 energy of the system conserved (STV of nitrate concentration in the aquifer) for the first ten eigenvalues is shown in Figure $5 \mathrm{~A}$. The results show that except the first eigenvalue that conserves about $96.2 \%$ of the energy of the system, the others are negligible. Thus, only the first mode may represent the STV of nitrate concentration in the Karaj Aquifer. Temporal and spatial components of the first mode $\left(\tau_{1}(t)\right.$ and $\left.\boldsymbol{\Theta}_{1}(\mathbf{x})\right)$ are shown in Figures 5B and 5C, respectively. According to Figure 5C, it is clear that the largest variation of nitrate occurs in the northern parts of the aquifer (shown in orange and blue color) in connection to urban areas as mentioned above. Indeed, high nitrate loads are introduced into the groundwater from residential areas due to the lack of sewage collection systems and using pit latrines for wastewater disposal. According to Figure 5B, the first temporal component $\left(\tau_{1}(t)\right)$ indicates a gradually increasing trend for nitrate concentration in the aquifer. This is due to the increase in population and development of agricultural lands, especially in recent years, and consequently increasing nitrate loads into the Karaj Aquifer. Figure 5B also indicates that the temporal variation of the other components is relatively 30 insignificant. 
Hydrol. Earth Syst. Sci. Discuss., https://doi.org/10.5194/hess-2018-222

\subsection{Results of nitrate ROM}

\subsubsection{Developing ROM for nitrate calculation}

In the study, two important principles were considered for the development of the nitrate ROM: (A) The accuracy should be similar to the results of MT3DMS, and (B) the model structure should be kept simple. For this purpose, a trade-off between

5 the model's accuracy and its complexity was performed. Figure 5D shows the RMSE for simulated nitrate concentrations by the MT3DMS and different ROMs developed with different number of modes. According to the figure, it is clear that increase in number of modes is accompanied by an increase in accuracy of the ROM. This increase in the models' accuracy is meaningful until the ROM developed by the first ten modes. Therefore, the nitrate ROM developed by the first ten out of 1,772 modes were used for simulation of nitrate in the aquifer. These ten modes together represent more than $99.99999 \%$ of the STV

10 of nitrate in the aquifer. The developed nitrate ROM was applied to simulate the nitrate concentrations for the aquifer during the calibration period. The spatial distribution of the simulated nitrate concentration by ROM and MT3DMS, as well as the difference between results of the two models for four selected days is presented in Figures 6A to 6D. According to the figures, the difference between results of the two models in different parts of the aquifer is less than $0.1 \mathrm{mg} / \mathrm{l}$ nitrate. This value is very small as compared to the large observed variation in nitrate concentration in the Karaj Aquifer (maximum nitrate concentration

15 is about $116 \mathrm{mg} / \mathrm{l})$. The mean error for each cell during the other four selected days are shown in Figures $6 \mathrm{E}$ to $6 \mathrm{H}$. The graphs show that the error varies between of -0.4 and $0.4 \mathrm{mg} / \mathrm{l}$ nitrate concentration. To better evaluate the accuracy of the ROM, nitrate concentrations simulated by ROM vs MT3DMS for the four different days are shown in Figures 6I to 6L. According to the figures, both models perform similar giving a correlation of about 1 for each of the days. Thus, it can be concluded that both models are equal in terms of accuracy.

\section{$20 \quad 3.4 .2$ Developing ROM for prediction purposes}

In order to develop ROM for prediction of nitrate concentration beyond the simulation period, it is necessary to calculate the temporal components of the first ten modes for future time step $t+n$. In this regard, one-year data from April 2012 to March 2013 was used. However, given the high importance of the temporal component of the first four modes that represent more than $99.99 \%$ of STV of nitrate in the aquifer, only the trend of these components are estimated in the future times $t+n$.

25 According to Figure 5B, for each component the best models were fitted. The fitted models with $\mathrm{R}^{2}$ equal to $0.999,0.995$, 0.959, and 0.892 for the first four temporal components, respectively, can be used to properly reconstruct these components for future time steps with good accuracy. The other temporal components were ignored due to their small contribution. Thereafter, having the spatial components of the first four modes, ROM was developed by application of Eq. (9) in the "Methods" section. Figures 7A to 7C show the spatial distribution of nitrate concentration simulated by ROM and MT3DMS,

30 respectively, as well as the difference between the model results for three selected days in 2012. According to the figures, maximum spatial difference between the models is less than $3 \mathrm{mg} / \mathrm{l}$ nitrate concentration. The results indicate that the absolute error is less than $0.5 \mathrm{mg} / 1$ nitrate concentration in the most parts of the aquifer. Thus, both models behave in a similar manner. 
Hydrol. Earth Syst. Sci. Discuss., https://doi.org/10.5194/hess-2018-222

Manuscript under review for journal Hydrol. Earth Syst. Sci.

Discussion started: 23 May 2018

(c) Author(s) 2018. CC BY 4.0 License.

It is noteworthy that the accuracy of the prediction is slightly lower than that obtained by ROM developed by the first ten modes. This is due to the use of the only first four out of first ten modes for development of ROM that conserved a lower percentage of the system energy compared to the first ten modes.

\section{Conclusions}

5 Some limitations of GQSMs were the main motivation for us to explore and present an alternative method to overcome these problems. In this regard, a ROM was developed by linking between MT3DMS and POD models and its performance was checked by simulation of nitrate concentration in the Karaj Aquifer, Iran. The developed nitrate ROM provided desirable results that matched the nitrate simulated by MT3DMS model well. More specifically, dominant variation of nitrate, based on the results obtained by spatial distribution of the first mode of nitrate, revealed the largest variations of nitrate in the northern

10 parts of the aquifer where occupied by dense population that using the septic wells for wastewater disposal. Also, the temporal component of the first mode indicated a gradually increasing trend of nitrate during the simulation period in the aquifer. The absolute error between the ROM and the MT3DMS was very small in most parts of the aquifer (about $0.5 \mathrm{mg} / \mathrm{l} \mathrm{nitrate}$ concentration) compared to the large observed variation in nitrate concentration (maximum nitrate concentration was about $116 \mathrm{mg} / \mathrm{l})$. In fact, the developed ROM with a much simpler structure had the same performance compared with MT3DMS.

15 Therefore, it can be concluded that the developed ROM was superior than MT3DMS. Indeed, the introduced methodology is general and it can be applied for simulation of target parameters in other fields of study.

\section{Author contribution}

Roohollah Noori and Mehrnaz Dodangeh conceived the study, collated the data, and ran the model. Farhad Hooshyaripor, Jan Franklin Adamowski, Saman Javadi, and Akbar Baghvand supervised the result analyses. Also, all authors contributed to the 20 writing and reviewing of the manuscript.

\section{Supporting information}

SI includes: Figure S1: observation wells, land use map, production wells, and groundwater table in the aquifer, Figure S2: thickness of the aquifer, Figure S3: spatial variation of calibrated hydraulic conductivity in the aquifer, Figure S4: spatial variation of recharge in the aquifer, and Figure S5: spatial variation of calibrated specific yields in the aquifer.

\section{Conflict of interest}

The authors declare no conflict of interest. 
Hydrol. Earth Syst. Sci. Discuss., https://doi.org/10.5194/hess-2018-222

\section{Acknowledgments}

This research was funded by the Center for Middle Eastern Studies, Lund University. The authors also are gratefully acknowledging the Iran Water Resources Management Company for cooperation in data preparation.

\section{References}

5 Abdelaziz, R. and Zambrano-Bigiarini, M.: Particle Swarm Optimization for inverse modeling of solute transport in fractured gneiss aquifer, J. Contam. Hydrol., 164, 285-298, https://doi.org/10.1016/j.jconhyd.2014.06.003, 2014.

Abdelaziz, R. and Le, H. H.: MT3DMSP-A parallelized version of the MT3DMS code, J. Afr. Earth Sci., 100, 1-6, https://doi.org/10.1016/j.jafrearsci.2014.06.006, 2014.

Abdelaziz, R. and Merkel, B. J.: Sensitivity analysis of transport modeling in a fractured gneiss aquifer, J. Afr. Earth Sci., 103,

10 121-127, https://doi.org/10.1016/j.jafrearsci.2014.12.003, 2015.

Ashrafi, K.: Determining of spatial distribution patterns and temporal trends of an air pollutant using proper orthogonal decomposition basis functions, Atmos. Environ., 47, 468-476, https://doi.org/10.1016/j.atmosenv.2011.10.016, 2012.

Bennacer, R. and Sefiane, K.: Proper orthogonal decomposition (POD) analysis of flow structure in volatile binary droplets, Int. Commun. Heat Mass., 71, 172-175, https://doi.org/10.1016/j.icheatmasstransfer.2015.12.036, 2016.

15 Boyce, S. E., Nishikawa, T., and Yeh, W. W.: Reduced order modeling of the Newton formulation of MODFLOW to solve unconfined groundwater flow, Adv. Water Resour., 83, 250-262, https://doi.org/10.1016/j.advwatres.2015.06.005, 2015.

Cardoso, M. A., Durlofsky, L. J., and Sarma, P.: Development and application of reduced-order modeling procedures for subsurface flow simulation, Int. J. Numer. Meth. Eng., 77, 1322-1350, https://doi.org/10.1002/nme.2453, 2009.

Conan, C., Bouraoui, F., Turpin, N., de Marsily, G., and Bidoglio, G.: Modeling flow and nitrate fate at catchment scale in

20 Brittany (France), J. Environ. Qual., 32, 2026-2032, https://doi.org/10.2134/jeq2003.2026, 2003.

Esfahanian, V. and Ashrafi, K.: Equation-Free/Galerkin-Free reduced-order modeling of the shallow water equations based on proper orthogonal decomposition, J. Fluids Eng., 131, 071401, https://doi.org/10.1115/1.3153368, 2009.

Gusyev, M. A., Abrams, D., Toews, M. W., Morgenstern, U., and Stewart, M. K.: A comparison of particle-tracking and solute transport methods for simulation of tritium concentrations and groundwater transit times in river water, Hydrol. Earth Syst.

25 Sci., 18, 3109-3119, https://doi.org/10.5194/hess-18-3109-2014, 2014.

Harbaugh, A. W., Banta, E. R., Hill, M. C., and McDonald, M. G.: MODFLOW-2000, The U. S. Geological Survey Modular Ground-Water Model-User Guide to Modularization Concepts and the Ground-Water Flow Process, Open-file Report. U. S. Geological Survey, (92), 134, 2000.

Johnson, A. I.: Specific yield: compilation of specific yields for various materials, 1967.

30 Kang, W., Zhang, J. Z., Ren, S., and Lei, P. F.: Nonlinear Galerkin method for low-dimensional modeling of fluid dynamic system using POD modes, Commun. Nonlinear Sci. Numer. Simul., 22, 943-952, https://doi.org/10.1016/j.cnsns.2014.07.030, 2015. 
Hydrol. Earth Syst. Sci. Discuss., https://doi.org/10.5194/hess-2018-222

Kostas, J., Soria, J., and Chong, M. S.: A comparison between snapshot POD analysis of PIV velocity and vorticity data, Exp. Fluids, 38, 146-160, https://doi.org/10.1007/s00348-004-0873-4, 2005.

Laattoe, T., Post, V. E., and Werner, A. D.: A spatially periodic solute boundary for MT3DMS and PHT3D, Groundwater 55, 419-427, https://doi.org/10.1111/gwat.12490, 2017.

5 Li, S. G., Liao, H. S., and Ni, C. F.: A computationally practical approach for modeling complex mean flows in mildly heterogeneous media, Water Resour. Res., 40, W12405, https://doi.org/10.1029/2004WR003469, 2004.

Mandle, R. J.: Groundwater modeling guidance. Michigan Department of Environmental Quality, GMP, draft, 1, 2002.

McPhee, J. and Yeh, W. W. G.: Groundwater management using model reduction via empirical orthogonal functions, J. Water Resour. Plan. Manage., 134, 161-170, https://doi.org/10.1061/(ASCE)0733-9496(2008)134:2(161), 2008.

10 Mehl, S.: Use of Picard and Newton iteration for solving nonlinear ground water flow equations, Groundwater 44, 583-594, https://doi.org/10.1111/j.1745-6584.2006.00207.x, 2006.

Noori, R., Yeh, H. D., Ashrafi, K., Rezazadeh, N., Bateni, S. M., Karbassi, A., Kachoosangi, F. T., and Moazami, S.: A reduced-order based CE-QUAL-W2 model for simulation of nitrate concentration in dam reservoirs, J. Hydrol., 530, 645-656, https://doi.org/10.1016/j.jhydrol.2015.10.022, 2015.

15 Noori, R., Abbasi, M. R., Adamowski, J. F., and Dehghani, M.: A simple mathematical model to predict sea surface temperature over the northwest Indian Ocean, Estuar. Coast. Shelf Sci., 197, 236-243, https://doi.org/10.1016/j.ecss.2017.08.022, 2017.

Noori, R., Asadi, N., and Deng, Z.: A simple model for simulation of reservoir stratification. J. Hydraul. Res. (Accepted for Publication), 2018.

20 Noori, R., Kheirabadi, H., Samani, J. M. V., Adamowski, J. F., Ranjbar, M. H., and Zaker, N. H.: Reduced-order simulation of surface currents in Gorgan Bay, Iran. J. Hydroinform. (Accepted for Publication), 2018.

Pasetto, D., Guadagnini, A., and Putti, M.: POD-based Monte Carlo approach for the solution of regional scale groundwater flow driven by randomly distributed recharge, Adv. Water Resour., 34, 1450-1463, https://doi.org/10.1016/j.advwatres.2011.07.003, 2011.

25 Pasetto, D., Putti, M., and Yeh, W. W. G.: A reduced-order model for groundwater flow equation with random hydraulic conductivity: Application to Monte Carlo methods, Water Resour. Res., 49, 3215-3228, https://doi.org/10.1002/wrcr.20136, 2013.

Pasetto, D., Guadagnini, A., and Putti, M.: A reduced-order model for Monte Carlo simulations of stochastic groundwater flow, Comput. Geosci., 18, 157-169, https://doi.org/10.1007/s10596-013-9389-4, 2014.

30 Pasetto, D., Ferronato, M., and Putti, M.: A reduced order model-based preconditioner for the efficient solution of transient diffusion equations, Int. J. Numer. Meth. Eng., 109, 1159-1179, https://doi.org/10.1002/nme.5320, 2017.

Peña-Haro, S., Pulido-Velazquez, M., and Sahuquillo, A.: A hydro-economic modelling framework for optimal management of groundwater nitrate pollution from agriculture, J. Hydrol. 373, 193-203, https://doi.org/10.1016/j.jhydrol.2009.04.024, 2009 . 
Hydrol. Earth Syst. Sci. Discuss., https://doi.org/10.5194/hess-2018-222

Manuscript under review for journal Hydrol. Earth Syst. Sci.

Discussion started: 23 May 2018

Peña-Haro, S., Llopis-Albert, C., Pulido-Velazquez, M., and Pulido-Velazquez, D.: Fertilizer standards for controlling groundwater nitrate pollution from agriculture: El Salobral-Los Llanos case study, Spain, J. Hydrol., 392, 174-187, https://doi.org/10.1016/j.jhydrol.2010.08.006, 2010.

Pulido-Velazquez, M., Peña-Haro, S., García-Prats, A., Mocholi-Almudever, A. F., Henriquez-Dole, L., Macian-Sorribes, H.,

5 and Lopez-Nicolas, A.: Integrated assessment of the impact of climate and land use changes on groundwater quantity and quality in the Mancha Oriental system (Spain), Hydrol. Earth Syst. Sci., 19, 1677-1693, https://doi.org/10.5194/hess-19-1677$\underline{2015}, 2015$.

Rasmussen, P., Sonnenborg, T. O., Goncear, G., and Hinsby, K.: Assessing impacts of climate change, sea level rise, and drainage canals on saltwater intrusion to coastal aquifer, Hydrol. Earth Syst. Sci., 17, 421-443, https://doi.org/10.5194/hess-

$10 \quad 17-421-2013,2013$.

Saghravani, S. R., Mustapha, S. A. B., Ibrahim, S. B., Yusoff, M. K., and Saghravani, S.F.: Phosphorus migration in an unconfined aquifer using MODFLOW and MT3DMS, J. Environ. Eng. Landsc., 19, 271-277. https://doi.org/10.3846/16486897.2011.634053, 2011.

Siade, A. J., Putti, M., and Yeh, W. W. G.: Snapshot selection for groundwater model reduction using proper orthogonal

15 decomposition, Water Resour. Res., 46, W08539, https://doi.org/10.1029/2009WR008792, 2010.

Stanko, Z. P., Boyce, S. E., and Yeh, W. W. G.: Nonlinear model reduction of unconfined groundwater flow using POD and DEIM, Adv. Water Resour., 97, 130-143, https://doi.org/10.1016/j.advwatres.2016.09.005, 2016.

Ushijima, T. T. and Yeh, W. W.: A proposed Fast algorithm to construct the system matrices for a reduced-order groundwater model, Adv. Water Resour., 102, 68-83, https://doi.org/10.1016/j.advwatres.2017.01.010, 2017.

20 Vermeulen, P. T. M., Heemink, A. W., and Te Stroet, C. B. M.: Reduced models for linear groundwater flow models using empirical orthogonal functions, Adv. Water Resour., 27, 57-69, https://doi.org/10.1016/j.advwatres.2003.09.008, 2004.

Vermeulen, P. T. M., Heemink, A. W., and Valstar, J. R.: Inverse modeling of groundwater flow using model reduction, Water Resour. Res., 41, W06003, https://doi.org/10.1029/2004WR003698, 2005.

Vermeulen, P. T. M., Te Stroet, C. B. M., and Heemink, A. W.: Model inversion of transient nonlinear groundwater flow models using model reduction, Water Resour. Res., 42, W09417, https://doi.org/10.1029/2005WR004536, 2006.

Zheng, C. and Wang, P. P.; MT3DMS: a modular three-dimensional multispecies transport model for simulation of advection, dispersion, and chemical reactions of contaminants in groundwater systems; documentation and user's guide, Alabama University, 1999. 
Hydrol. Earth Syst. Sci. Discuss., https://doi.org/10.5194/hess-2018-222

Manuscript under review for journal Hydrol. Earth Syst. Sci.

Discussion started: 23 May 2018

(c) Author(s) 2018. CC BY 4.0 License.

\section{Figure Captions}

Figure 1: The Karaj Aquifer located in northern Iran

Figure 2: Methodology used for the present study

Figure 3: Difference between simulated and observed groundwater levels during the calibration of MODFLOW: (A) under unsteady state 5 condition for Ghezel-hesar piezometer located in the northwestern part of the aquifer, (B) under unsteady state condition for Marlik piezometer located in the southern part of the aquifer; $(\mathbf{C})$ Temporal variation of mean absolute error (MAE) and root mean square error (RMSE) during the one-year verification of MODFLOW; Difference between simulated and observed nitrate concentration during the calibration of MT3DMS under unsteady state condition in: (D) Golshahr piezometer, (E) Mehrshahr piezometer, and (F) Meshkin piezometer

Figure 4: Spatial distribution of nitrate concentration in the Karaj Aquifer for six selected days (A) $15^{\text {th }}$ September 2006, (B) $15^{\text {th }}$ April $102007,(\mathbf{C}) 15^{\text {th }}$ July 2008, (D) $15^{\text {th }}$ November 2009, (E) $15^{\text {th }}$ August 2010, (F) $15^{\text {th }}$ February 2011

Figure 5: (A) Eigenvalues and corresponding eigenvectors with energy of the system conserved for the first ten eigenvalues calculated by application of POD, $(\mathbf{B})$ temporal components of first to fourth modes $\left\{\tau_{1}(\mathrm{t})\right.$ to $\left.\tau_{1}(\mathrm{t})\right\},(\mathbf{C})$ spatial component of the first mode $\left\{\Theta_{1}(\mathrm{x})\right\}$, $(\mathbf{D})$ root mean square error (RMSE) for nitrate concentrations simulated by MT3DMS and ROMs with different number of modes

Figure 6: Spatial distribution of nitrate concentrations simulated by ROM, MT3DMS, and difference between the two model results for 15 four selected days: (A) $15^{\text {th }}$ September 2006, (B) $10^{\text {th }}$ June 2007, (C) $10^{\text {th }}$ April 2008, (D) $10^{\text {th }}$ January 2010; Mean error in each cell for four selected days: (E) 15 ${ }^{\text {th }}$ November 2006, (F) 12 ${ }^{\text {th }}$ May 2008, (G) 14 ${ }^{\text {th }}$ September 2009, (H) 08 ${ }^{\text {th }}$ February 2010; Nitrate concentrations simulated by ROM vs MT3DMS for four different days: (I) $05^{\text {th }}$ December 2006, (J) $26^{\text {th }}$ August 2007, (K) 20 $0^{\text {th }}$ April 2009, (L) $12^{\text {th }}$ May 2010

Figure 7: Spatial distribution of nitrate concentrations simulated by ROM and MT3DMS, and difference between the models for three selected days beyond the simulation period: (A) 21 $1^{\text {th }}$ May 2012, (B) $18^{\text {th }}$ September 2012, (C) 04 ${ }^{\text {th }}$ February 2013 
Hydrol. Earth Syst. Sci. Discuss., https://doi.org/10.5194/hess-2018-222

Manuscript under review for journal Hydrol. Earth Syst. Sci.

Discussion started: 23 May 2018

(c) Author(s) 2018. CC BY 4.0 License.

Hydrology and Earth System Sciences (c) (1)

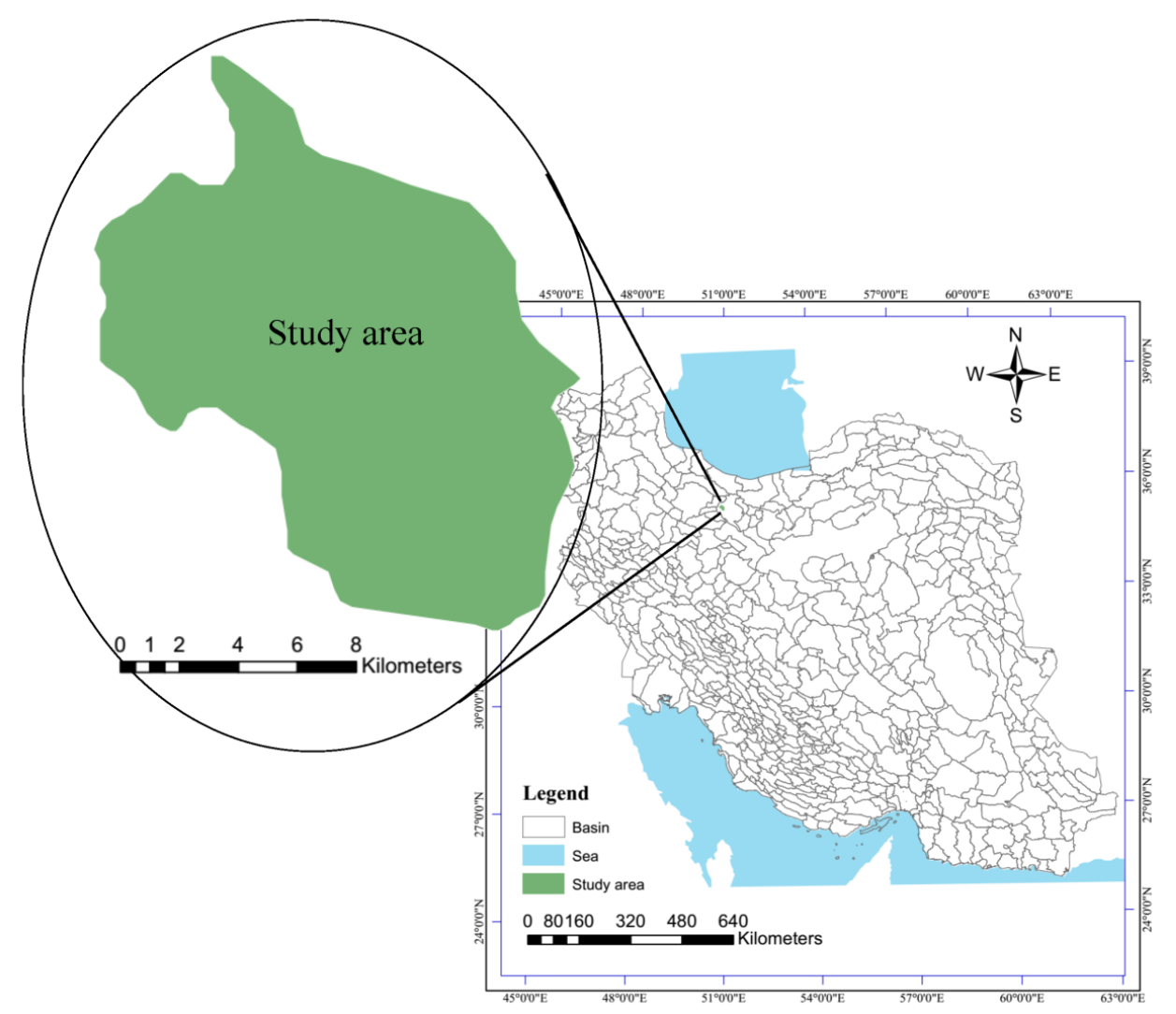

Figure 1 
Hydrol. Earth Syst. Sci. Discuss., https://doi.org/10.5194/hess-2018-222

Manuscript under review for journal Hydrol. Earth Syst. Sci.

Discussion started: 23 May 2018

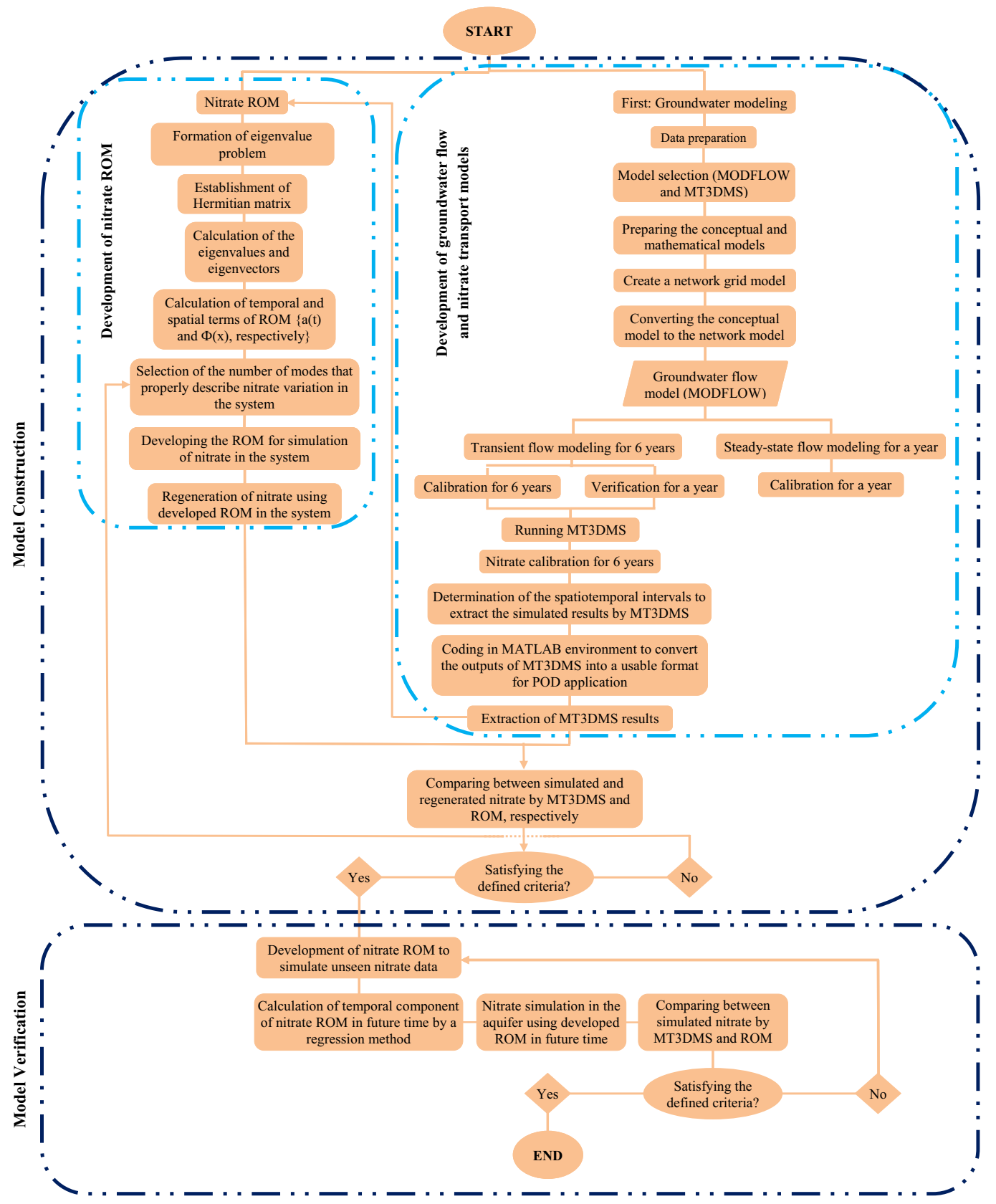

Figure 2 
Hydrol. Earth Syst. Sci. Discuss., https://doi.org/10.5194/hess-2018-222

Hydrology and Manuscript under review for journal Hydrol. Earth Syst. Sci.

Discussion started: 23 May 2018

$\mathbf{A}$

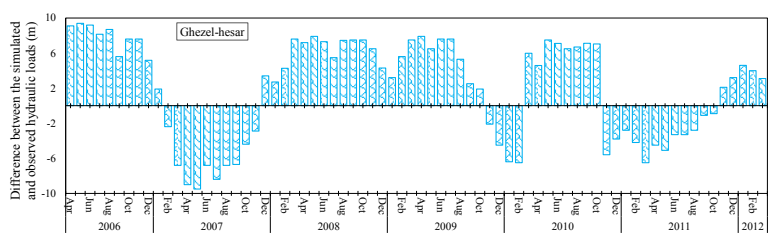

C

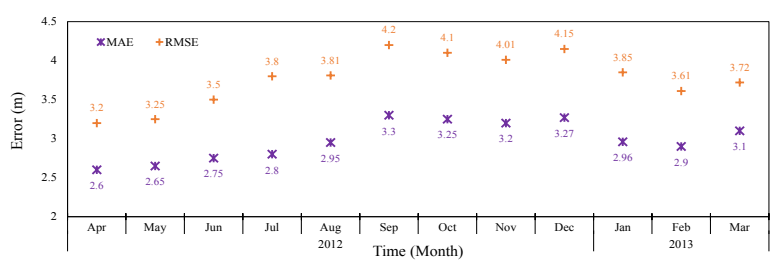

E

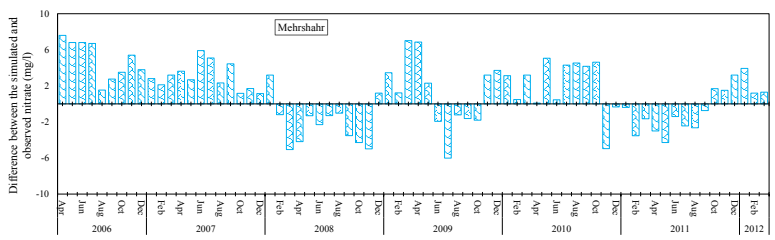

B

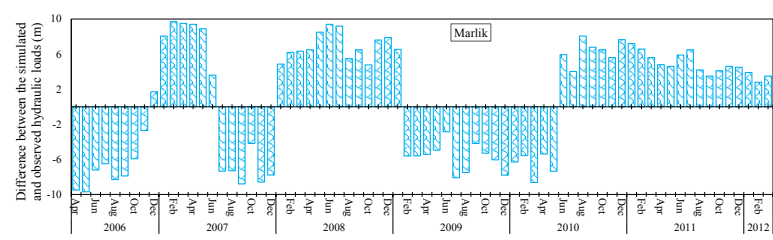

D

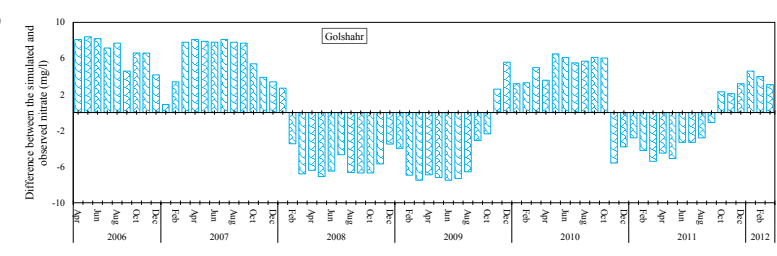

F

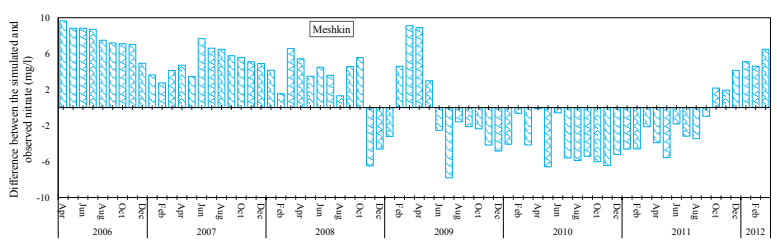

Figure 3 
Hydrol. Earth Syst. Sci. Discuss., https://doi.org/10.5194/hess-2018-222

Manuscript under review for journal Hydrol. Earth Syst. Sci.

Discussion started: 23 May 2018

(c) Author(s) 2018. CC BY 4.0 License.

\section{Hydrology and Earth System

A

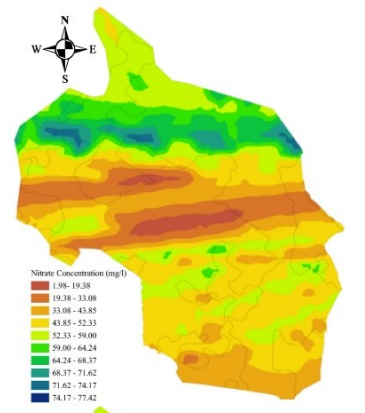

D

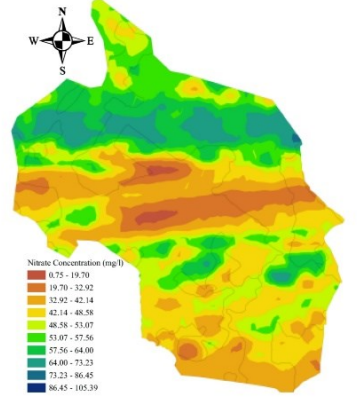

B

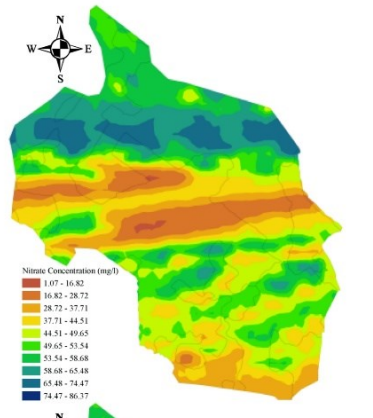

$\mathbf{E}$

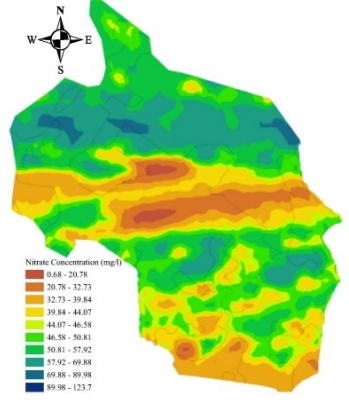

C

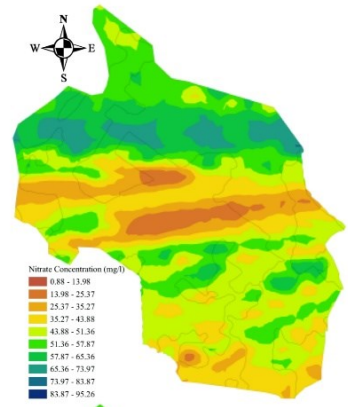

$\mathbf{F}$

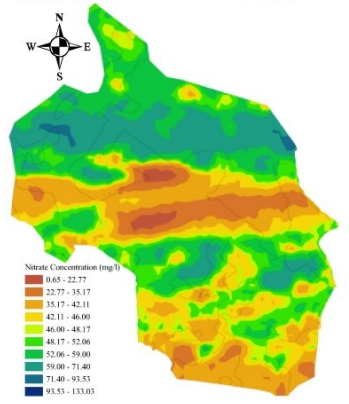

Figure 4 
Hydrol. Earth Syst. Sci. Discuss., https://doi.org/10.5194/hess-2018-222 Manuscript under review for journal Hydrol. Earth Syst. Sci.

Discussion started: 23 May 2018

(c) Author(s) 2018. CC BY 4.0 License.

(c) (1)

A

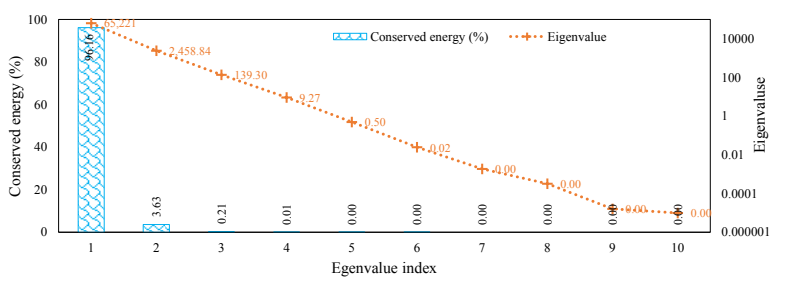

B
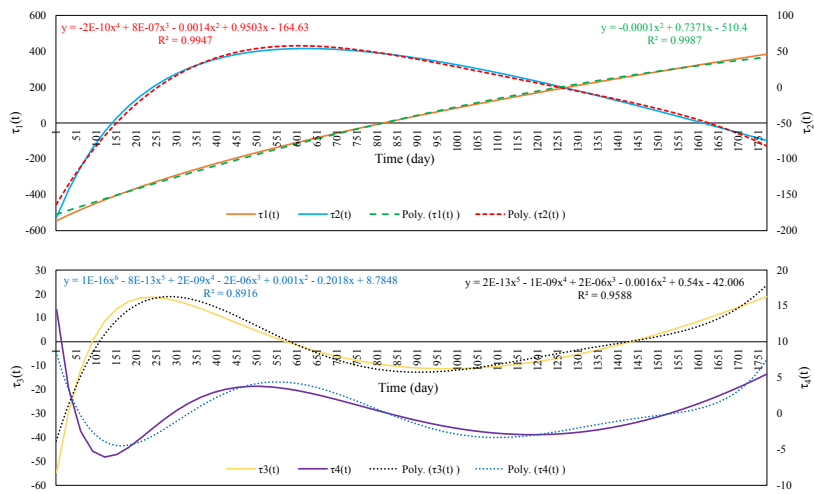

Hydrology and Earth System Sciences Discussions

C

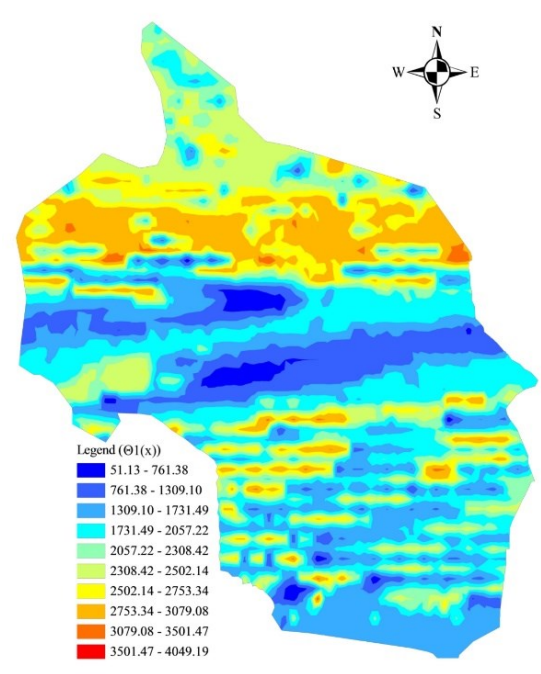

D

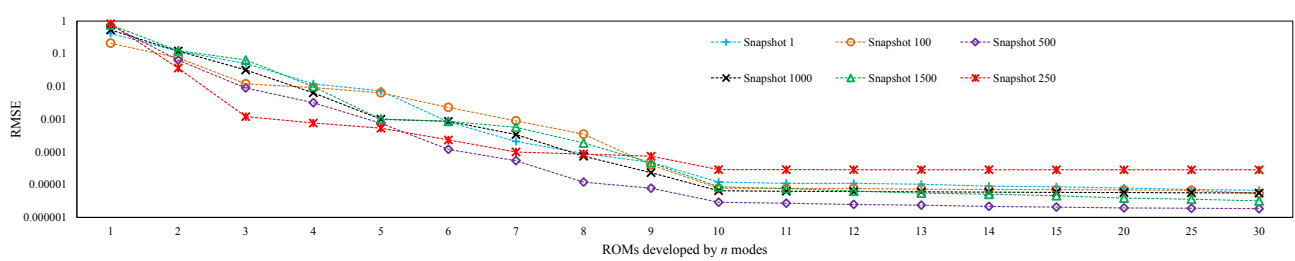

Figure 5 
Hydrol. Earth Syst. Sci. Discuss., https://doi.org/10.5194/hess-2018-222

Manuscript under review for journal Hydrol. Earth Syst. Sci.

Discussion started: 23 May 2018

(c) Author(s) 2018. CC BY 4.0 License.
A
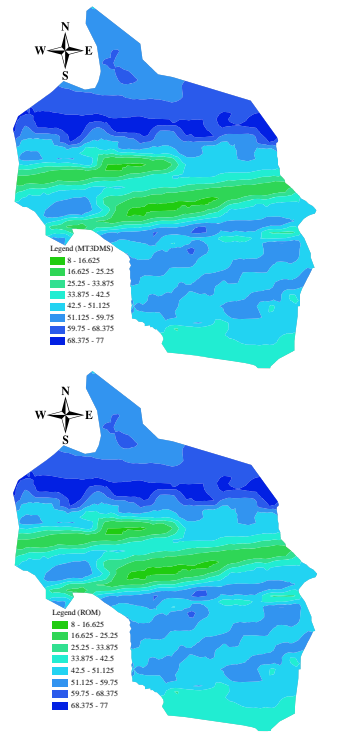

$\underset{s}{n}$

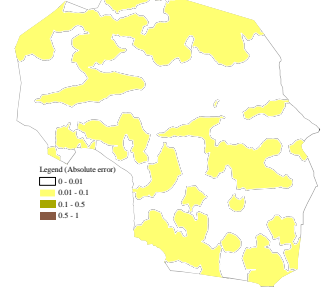

B
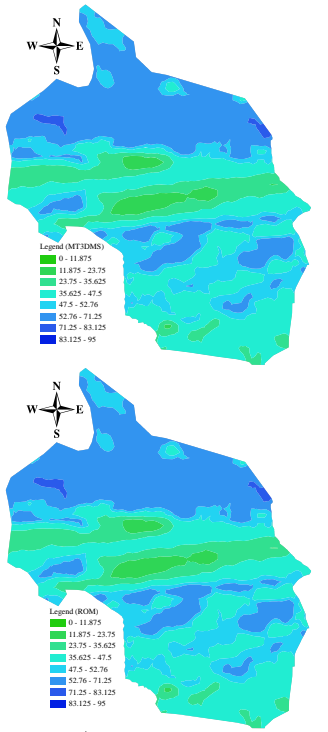

$\operatorname{tr}_{\mathrm{E}}^{\mathrm{N}}$

E

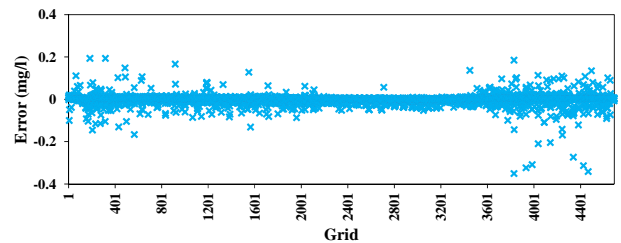

G

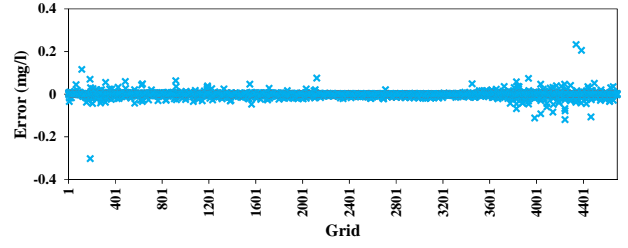

C
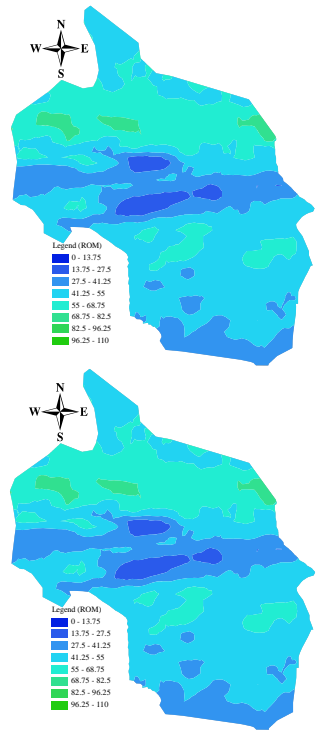

$\underset{s}{n+1}$

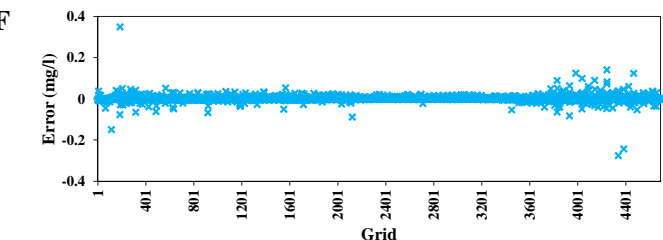

H

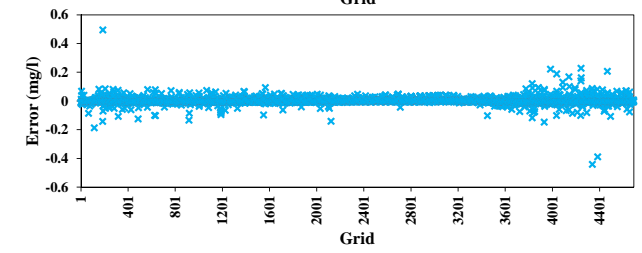

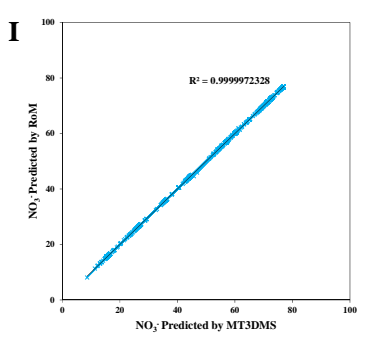

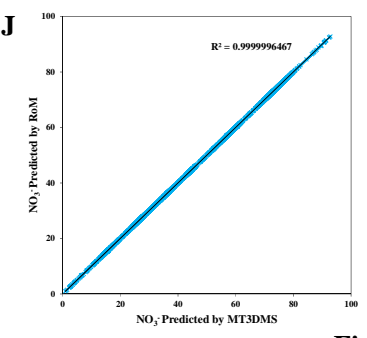

Hydrology and Earth System Sciences

Discussions

D
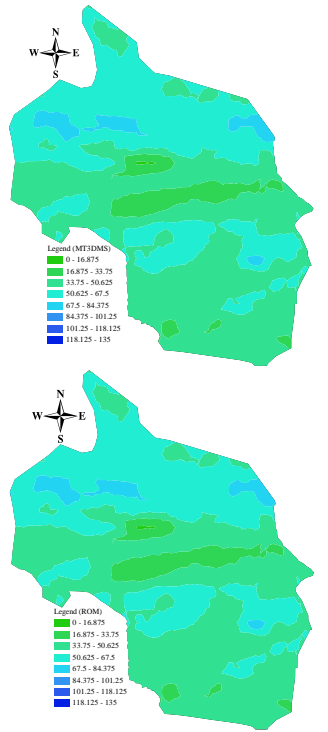

$\sin ^{n}$

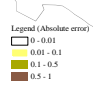

. 
Hydrol. Earth Syst. Sci. Discuss., https://doi.org/10.5194/hess-2018-222

Manuscript under review for journal Hydrol. Earth Syst. Sci.

Discussion started: 23 May 2018

(c) Author(s) 2018. CC BY 4.0 License.

(A)
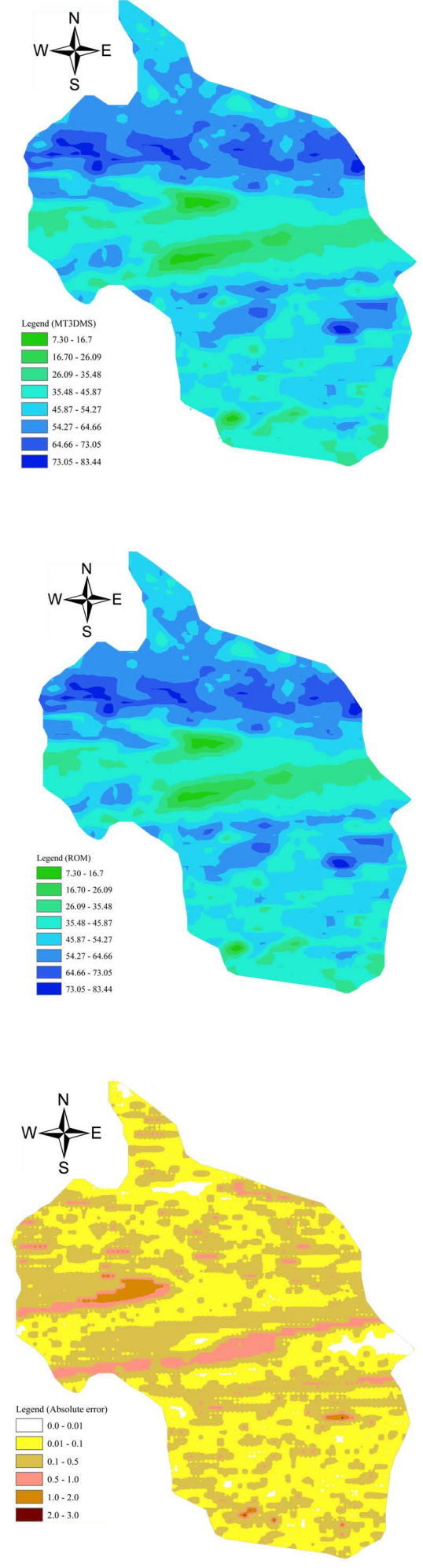

(B)
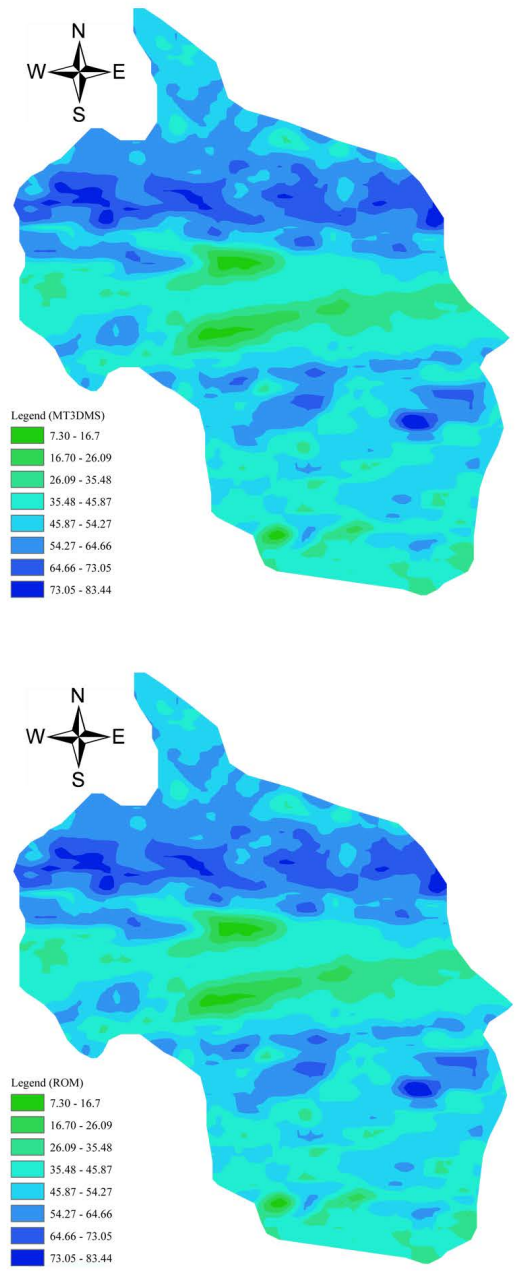

$\hat{\beta}_{S}^{N}$

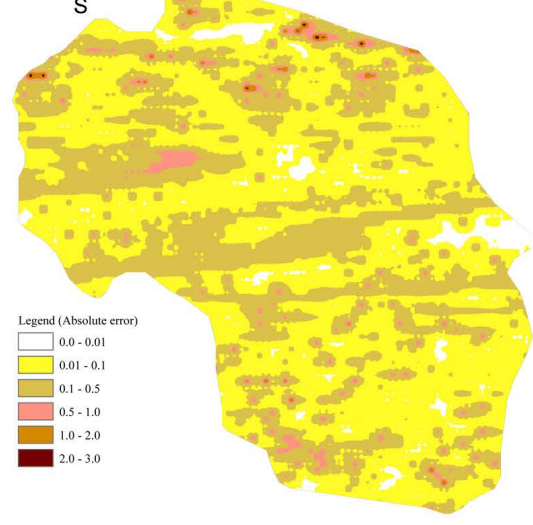

Figure 7

\section{Hydrology and Earth System Sciences \\ Discussions

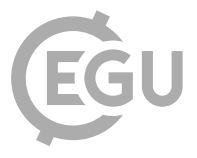

(C)
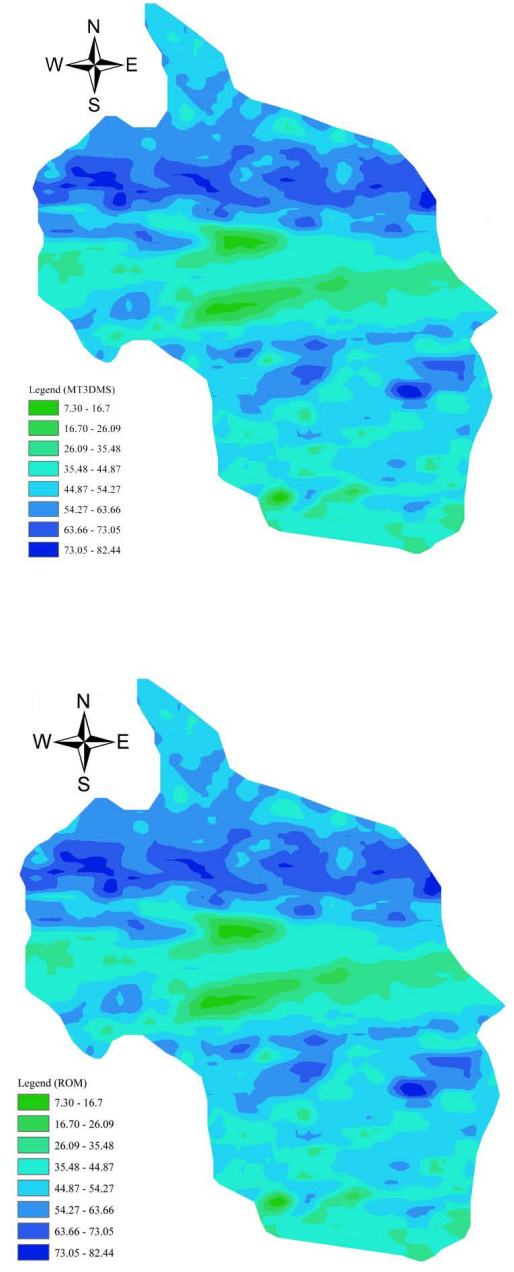

${ }_{S}^{N} E=$

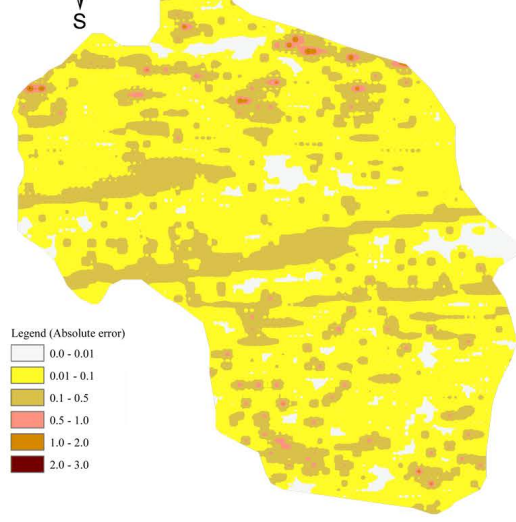

